
Resilience

\title{
Failed promises: governance regimes and conflict transformation related to Jatropha cultivation in Ethiopia
}

\author{
Fekadu A. Tufa ${ }^{1,2}$, Aklilu Amsalu ${ }^{3}$ and E. B. Zoomers ${ }^{4}$
}

\begin{abstract}
Conflict over natural resources is a widespread phenomenon in the global south. Trends in consumption, demographics, environmental degradation, and socio-political dynamics are exerting significant pressure on the availability and accessibility of natural resources. In many countries, the governance of land for commercial agricultural investment leads to conflict. Such conflicts are complex, and the drivers extend beyond resource scarcity to issues of access and competition. This paper is based on the results of field research on investments in large-scale Jatropha plantations for biofuel production in Ethiopia. A case study of a large-scale Jatropha plantation in eastern-central Ethiopia is used to reconstruct the history of a short-lived, large-scale biofuel development in Ethiopia, and to examine the processes and the reasons for its failure. Between 2006 and 2009, more than 400,000 ha of land were acquired for industrial biofuel development. Given the country's dependence on imported fossil fuels and the global rush for alternative energy sources, the Ethiopian government, not surprisingly, gave emphasis to investment in biofuel development, mainly through Jatropha plantation. However, after costly experimentation, the "miracle crop" did not deliver what had been promised. Instead, it dispossessed and displaced thousands of marginalized local smallholder agropastoralists, created conflict over water and land resources, and kept thousands of hectares of land out of production. In the end, the rhetoric of "Jatropha revolution" and promises of local and national development were never materialized; the government's ambitious biofuel strategy also failed to achieve its objectives. The main argument of this paper is that the failure of large-scale biofuel companies to fulfill their ambitious promises in Ethiopia is part of the general failure in the governance of large-scale commercial agriculture and misleading views toward, and unrealistic promises of, Jatropha investments. These negatively affected the livelihood of the local agropastoralists and their interactions with the companies, which caused instabilities and conflicts in the area. It is hoped that the findings of this research will contribute to knowledge production and policies on the governance of large-scale commercial agriculture.
\end{abstract}

Key Words: biofuels; conflict; Ethiopia; land governance; large-scale investments; political economy

\section{INTRODUCTION}

Our company works to transform the area from poor food aid recipient to an economic hub that would even support people from beyond the region. We will set up an oil processing plant in the locality to produce aviation fuel from Jatropha that would also help create thousands of job opportunities (interview with former employee of Emami Biotech).

This quotation is a recollection by a former employee regarding the speech made by the manager of Emami Biotech Jatropha Plantation Company (hereafter Emami Biotech) during the 2009 public engagement session with the local communities and officials in Miesso District, West Hararghe Zone of Oromia National Regional State, Ethiopia. Emami Biotech was one of the 52 biofuel companies that secured a license between 2006 and 2009 to invest in large-scale Jatropha plantations in the country. These companies acquired more than 400,000 ha of land for biofuel investments through large-scale plantation and outgrower schemes. This was the first phase of land acquisition, and the total land requested by the companies to bring about a "biofuel revolution" in the country added up to 1.68 million hectares (MELCA Mahiber 2008).

These rhetorical promises to contribute to local and national development were meant to justify the land acquisition decisions, by overemphasizing the relevance of the company's work, and legitimize the possible negative impact of the investments on local communities. It also echoed the Ethiopian government's ambitious development plan aimed at, ostensibly, transforming the country's economy into a middle income standard in the coming decade. The large-scale agricultural investments, including biofuels, are expected to contribute to this national strategy (MoARD 2010). In less than a decade, however, almost all the biofuel companies that were licensed and that acquired land for Jatropha plantation have failed in their operations, and most of them, including Emami Biotech, completely abandoned their investments.

This study reconstructed a history of biofuel development by using the case of large-scale Jatropha investment located in the Awash valley of eastern-central Ethiopia, and emphasized localized dynamic relationships between the government/s, the investment company, and the local community. The study concluded that the biofuel investments failed to fulfill all the promises made prior to land acquisition and investment, viz. (1) development of infrastructure for social services and creation of employment opportunities for local communities that have been dispossessed of their land for the purpose of the investments, and (2) contributing to national energy security and the broader development. The study also found that competitions and conflicts with local pastoral and agropastoral communities over land and water, inability (of the company and the government/s) to handle relationships with the locals, and technical problems such as shortage of water for irrigation and unsuitability of soils for Jatropha production were among the major specific reasons for the failure of the investment.

\footnotetext{
${ }^{1}$ Addis Ababa University, ${ }^{2}$ Department of Social Anthropology, ${ }^{3}$ Addis Ababa University, Department of Geography and Environmental Studies,

${ }^{4}$ International Development Studies, University of Utrecht, The Netherlands
} 
In the same vein, we argue that the failure of the biofuel investments (failure to fulfill their promises) that could contribute to local and national development was a reflection of the general failure in land governance and development strategies of the country. That is, the overarching reason for the failure of the investment was structural. It included an ambitious and top-down approach, implementation without proper planning, decisionmakers' misconceptions about benefits of large-scale investments and the state of local resources, lack of appropriate consultation with local communities, and underestimating (undermining) local people's interest and their power of resistance, all of which have contributed to the failure of biofuel investments. Consequently, the approach and the subsequent exercise destabilized local livelihood and social relations, in addition to the failure of investments initiatives.

In the following sections, we briefly discuss land governance and the national development strategies, the urge for biofuel investment, and some misconceptions about availability of land, land rights, and land use patterns in the agropastoral areas of Ethiopia. This helps contextualize the present study on the Jatropha investment in the specific political economy of the country.

\section{Land governance and development strategies}

Land governance is contested in Ethiopia, with land tenure being one of the most persistently debated topics on the public political agenda. The country has undergone major political changes over the past four decades. The changes have been accompanied by major land reforms, from a predominantly feudal system that simultaneously recognized kinship, tenancy, and private forms of tenure to a socialist regime that instituted public ownership of land, involving nationalization and redistribution of land to peasant households. Under the current government, land still remains public property and constitutionally entrenched (FDRE 1995:Article 40). Land tenure debates have been revolving largely around public versus private options. The government believes that land privatization would encourage land sale, which in turn exposes smallholder peasants and pastoralists to land speculation, land grabbing, and eventually eviction, leading to a high number of unemployed peasants and pastoralists (Hussein 2001, Desalegn 2011).

Recently, ironically, the same government has been engaged in massive land leases to large-scale foreign and domestic investors, which has been displacing thousands of smallholders. As a result, the country has become one of the "hot spots" for international commercial agro-investments (Lorenzo et al. 2009, Oakland Institute 2010, Deiniger et al. 2011, Schoneveld 2014). Keeley et al. (2014), citing government sources, indicated that 2.2 million hectares of land had been given out to investors up to 2012, while the Oakland Institute (2011) put the figure up to January 2011 at more than 3.6 million hectares. Furthermore, the Ethiopian government had targeted to transfer an additional 3.3 million hectares of land to private investors in its five-year (2010-2015) strategic Growth and Transformation Plan (MoFED 2010). According to Desalegn (2011), had this target been met, Ethiopia would have leased $38 \%$ of the total national land under smallholder land holdings. The figures are disputed; nevertheless, it is obvious that a significant amount of land has been given out.
For the smallholders, who have listened to the government's rhetoric of protecting the poor from land grabbers but who have been dispossessed of their land and displaced from their livelihood by the same government, the existing system of land governance fails to deliver its promises. Actually, by controlling land, the successive Ethiopian regimes have retained for themselves a monopoly of political power and the legal provisions to be the main players in the massive land enclosures and landgrab-related dispossessions and displacements (Makki 2012, Hall 2013).

The state's interest in (and power over) land is evident in the place given to land in the national development strategy and the modalities of availing land when it is needed for the same purpose. That is, land acquisition for large-scale commercial agriculture in the country is not driven merely by the new global economic processes but is also embedded in the country's development strategies. A close review of the series of evolving land-based (rural-agricultural) development strategies of the Ethiopian government shows a shift from production for consumption that focused on smallholders (1990s-2000s) to increased focus on commercialization, mainly through large-scale plantations, including biofuel feedstock (2006-2016) (MoARD 2006, 2010). The stagnation of smallholder agriculture, coupled with persistent food insecurity and shortage of foreign currency in the country might have led to the anticipation that commercialization of agriculture would be a solution (Lavers 2012).

It is widely recognized that the global land rush, which was triggered by the $2007 / 8$ world financial, fuel, and food price crisis, considerably contributed to problems in the country (Cotula et al. 2009, Deininger et al. 2011, Makki 2012). This coincidence of the global rush for land in developing countries and the Ethiopian government's agricultural policy shift exacerbated the problem, resulting in a massive transfer of land to foreign and domestic investors. However, the strong desire of the Ethiopian government to meet domestic political and development-related demands by aggressively leasing out land to investors failed to consider the immediate livelihood needs of the local people.

\section{The urge for biofuel investment}

Imported fossil fuel constituted $94 \%$ of Ethiopia's energy consumption (Abreham and Belay 2015). Due to population growth and relative economic dynamism in the country, the demand for fossil fuels increased tremendously in the first decade of the new millennium. This has worsened the burden of this landlocked country to meet the rising need for imported fuel. For instance, demand for fuel increased from 1.1 million metric tons in the fiscal year 2000/01 to 1.9 million metric tons in the fiscal year $2007 / 08$. The import values even grew disproportionately higher from US\$0.27 billion to US\$1.6 billion in the same time period. In the fiscal year $2013 / 14$, the amount almost reached US\$2 billion, which is about $25 \%$ of the country's annual budget (interview with director of the biofuel department in the Ministry of Water, Mineral and Energy).

With the global energy crisis in the year 2007/08, the import price of fossil fuels exceeded the country's annual export earnings, which resulted in a negative balance of trade (MELCA Mahiber 2008). The Ethiopian government's biofuel strategy clearly presents the rationale for biofuel development from this 
perspective; i.e., "to produce adequate biofuel energy from domestic resources for substituting imported fossil fuel products and to export the excess produced" (MME 2007:9). Apart from biofuel development, it has been argued that large-scale biofuel feedstock investments would boost rural development through diversification by creating employment opportunities and improving smallholders' income from the production and sale of feedstock. Further, it was supposed to serve as a mechanism for technology transfer and contribute to the country's overall development (MoARD 2010). While many countries present replacing fossil fuels with biofuels as a crucial policy goal as a strategy for climate change mitigation (Abreham and Belay 2015), the ambition of the Ethiopian government was rather to achieve immediate economic goals, such as energy security and improvement of the balance of trade through import substitution; it even sought to create a new export sector from biofuel.

This ambitious energy policy also appeared in the Growth and Transformation Plan in 2010, which came into effect three years after the biofuel strategy was implemented. According to this strategy, Ethiopia has large tracts of land that are suitable for biofuel development, and there is the urge to increase the biofuel production by engaging private investors, both domestic and foreign. In fact, a target has been set to increase the production of biodiesel by up to 1.6 billion litres and to generate one billion dollars in foreign currency annually from the sector through the involvement of private investors and farmers (MoFED 2010:49).

A range of feedstock can be used for biofuel productions. Molasses, the by-product from sugar production, is the preferred feedstock for ethanol production, while Jatropha is the preferred crop for production of biodiesel. Jatropha was preferred as the prime feedstock for biodiesel production by the Ethiopian government and the investors, based mainly on the assumption that the plant can easily thrive in arid and degraded areas, has a cheaper cost of production, and has good yield/productivity (MME 2007).

\section{Double misconceptions: agropastoral land and Jatropha}

Awash valley, the location of the Jatropha plantation we discuss, is an agropastoral area that has been experiencing what Fouad Makki (2012:85) called an "extensive process of dispossession" (Fig. 1). It is a "historical example of the conversion of pastoralist land to large-scale irrigated crop production" in Ethiopia (Abbink et al. 2014:18). Beginning in the 1960s, when there was little mechanized agriculture in the country, agropastoralists in the Awash River basin experienced severe development-induced marginalization, dispossession, and displacement. The fact that Awash valley is geographically closer to Addis Ababa, as compared to other lowland peripheries of the country such as Gambella, Benishangul Gumuz, and South Omo, made it the primary victim of the state's predatory characteristics (Ayalew 2012, Makki 2014).

In Ethiopia, center-periphery arguments are common in statesociety relationships. The Ethiopian state is viewed by its lowland peripheral citizens as a de facto representative of the dominant center, ideologically linked to the agricultural highland as opposed to the lowland agropastoralists (see Markakis 2011, Lavers 2012, Makki 2012, 2014, Gebresenbet 2016). Successive regimes held the common misconception that land is abundant in the pastoral and agropastoral areas of the lowland peripheries.
Policy-makers imagined and constructed the lowland territory as sites of "bountiful emptiness" - a territory empty of people but full of resources that have been underutilized (Bridge 2001, as cited in Korf et al. 2015:882) or as a "wasteland" that they discursively labeled as not being put to proper use and that awaits to be transformed into a "productive landscape" (Borras et al. 2010:581) through the use of modern technology and mechanized large-scale development schemes (Gill 2015).

Makki (2014) has discussed this notion of labeling pastoral lowlands of Ethiopia as empty of people as terra nullius. According to this discourse, the state and development actors can claim possession of such land because there is no legally entitled group/person to pose claims upon land declared empty. Makki (2014:89) wrote that "For the state builders in the highland core the western and eastern lowlands had historically constituted a virtual no-man's land ...”. The agropastoral communities inhabiting this semi-arid lowland live on livestock herding, and farming shaped by the availability of rain, which is erratic. The area is sparsely populated and covered by green acacia trees. Satellite images, which the state claimed to have used for land identification for investment, can easily hide the reality on the ground. The sparsely populated areas covered by green bush were apparently taken as a pretext to support the official rhetoric of the government that label the lowland agropastoral areas as "idle" or "underutilized" land waiting for "capitalist redemption" (Makki 2014). Such lands are made available for lease to largescale private investors and are given to the state-owned large-scale investments (see Tewolde and Gebresenbet 2014). The local people have been dispossessed and displaced without claim to any kind of compensation because they are not accepted as legitimate owners of the land, and the land they occupy is considered unutilized and therefore can be violently appropriated. However, the local people are not passive receivers of the government decisions and the companies' actions (see Culmination of resistance and abandonment).

The second misconception is related to the way the development planners situated Jatropha in this predatory expansion of the centrally planned development projects to the lowland peripheries. The riverside irrigable part of the lowland peripheries such as the alluvial soils along the Awash valley in central and eastern Ethiopia, which is not far from the research site on which this paper is based, the Baro River basin in Gambela, the GibeOmo Valley in the south, and the Wabi-Shebele basin in the east are areas with great potential for the production of food crops, sugarcane, cotton, fruits, and vegetables. Most of the Jatropha investments were made in the so-called "marginal areas" of the lowlands, where it was supposed to be able to grow on degraded land without competing with food crop production.

The belief that Jatropha can grow effectively on semi-arid lowland emboldened the investors to start operations without properly undertaking even a basic technical study on the suitability of soil and water availability before beginning operations (interview with Oromia Investment Official, December 2014). Later on, many companies complained about the unsuitability of the land and the shortage of water for the cultivation of the plant. According to the rapid assessment of the land allocated to biofuels in 2008, more than $80 \%$ of the biofuel investments in Ethiopia were made on arable lands, forest lands, and woodlands (MELCA Mahiber 
Fig. 1. Map of the study site.

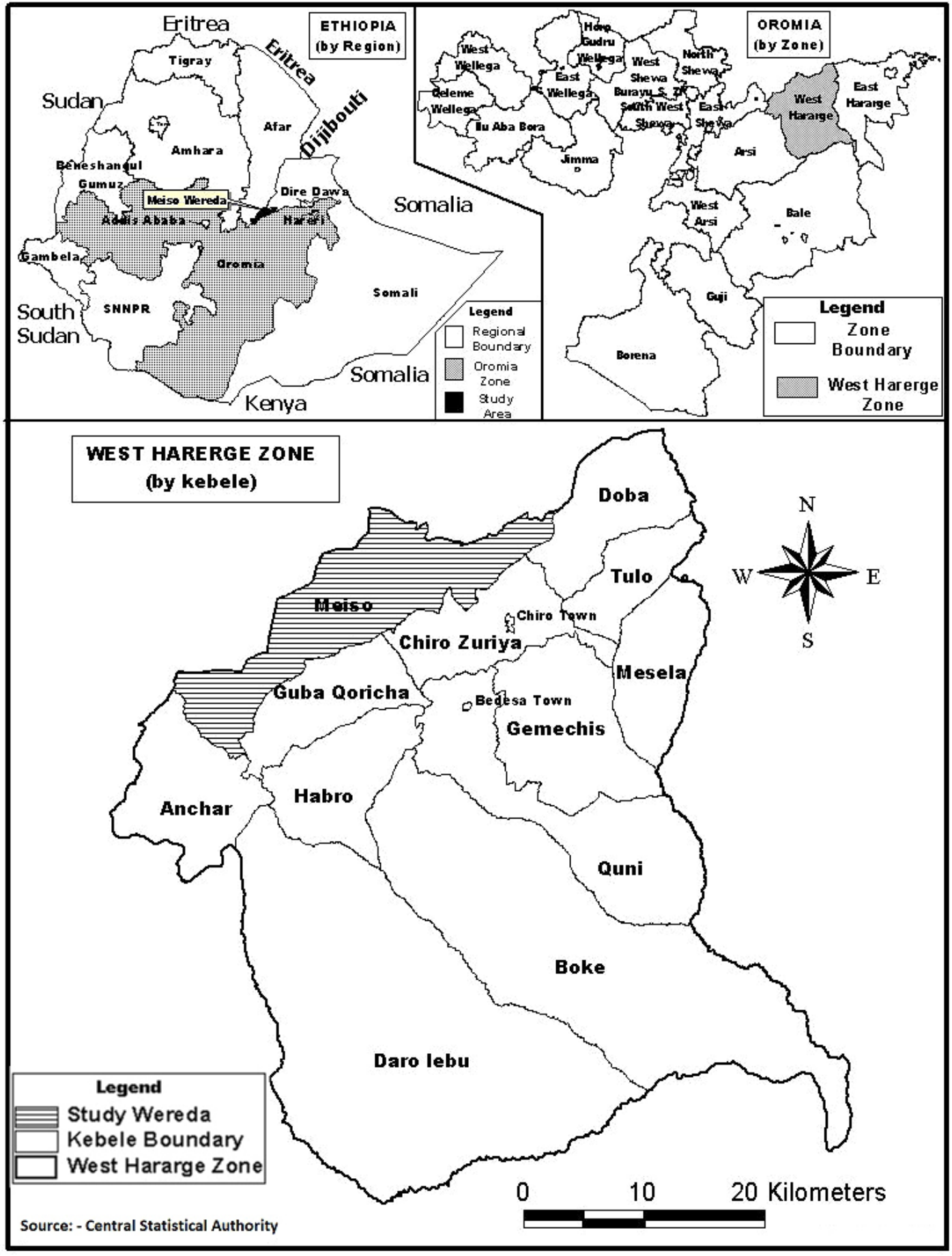

2008:2). In other words, contrary to the claims, most of the land acquired for biofuel was not marginal land.

These misleading views about the state of agropastoral land and Jatropha, coupled with the government's ambitious energy policies, caused two problems. Firstly, it affected the government's and the investors' understanding of the local community's relation to their land and consequent responses. Secondly, it undermined the need for the seemingly procedural but very crucial socioeconomic, environmental, and other technical studies about the land. Both contributed to crippling the investment. 


\section{METHODS}

The data for this study were gathered through fieldwork conducted in the Awash valley, Miesso District of Oromia National Regional State, east-central Ethiopia (Fig. 1), where the Emami Biotech Jatropha Plantation was located. Although data were collected from two other Jatropha investment sites situated in northern and southern Ethiopia, Emami Biotech was found to be the most interesting case because it was the biggest, most active, and most promising biofuel investment when this study started. At the national and regional levels, data were collected from the federal and Oromia National Regional State investment offices. The data gathering took place in two phases. The first phase took place in 2010 and 2011 when the investment was active and Jatropha appeared to be flourishing. The second phase of fieldwork was conducted in 2013 after the investment was abandoned and Jatropha plants were destroyed and changes in land use occurred.

In terms of instruments of data collection, indepth semistructured interviews, focus group discussions (FGD), and observations were used. In both phases, we interviewed 26 informants and held nine FGDs, ranging from six to eight participants, of whom two participants were women. The informants and the FGD participants were selected purposively from the local community, company officials, and employees (and ex-employees) based on their engagements and knowledge of the company's activities and the multiple interactions between the company and the locals. Government officials at different levels, including the district, the regional, and the federal, were interviewed. At the district level, administrators, experts in the offices of Land Use and Environment and Agriculture and Rural Development, were targeted. Officials in the Oromia National Regional State's Investment Bureau, which played the major role in Jatropha investment from land acquisition to supervision, and the Federal Investment Agency and the Ministry of Mining and Energy (to which the Biofuel Directorate belongs), which oversee the investment, were also interviewed.

Personal observation was helpful to understand the physical environment where the investment was made, and the local communities' livelihood and the natural resources, which were the centers of cooperation and conflict in the relationship between the investment and the local communities. We also consulted various documents on the Ethiopian development policies in general and the biofuel investment policies in particular.

\section{RESULTS AND DISCUSSION}

\section{Emami Biotech's investment and land acquisition process}

In 2009, Emami Biotech Jatropha Plantation Company, a subsidiary of the Emami Group based in Calcutta, India, was granted 11,000 ha of land in lease in Miesso District in the locality known as Bordede. This was the first phase of the 42,000 ha that the company requested and the Oromia National Regional State's Investment Bureau promised to provide. The lease was renewable in 45 years. The company had announced that it planned to invest US\$83 million in five years to plant Jatropha and other oil seeds, and to set up a biofuel processing plant close to the farm site. It had been estimated that, upon completion, the project would produce 100,000 tons of crude biofuel annually (Business Standard 2009, Mengistu 2013).
The Emami Group's involvement in biofuel investment in Ethiopia was initiated in 2008 when the President of Oromia National Regional State visited Calcutta. The President, accompanied by the Ethiopian ambassador to India, approached Aditya Agarwal, head of the Emami Group, and invited him to invest in biofuels in Ethiopia. Betting big on the potential of the West Bengal region of India in the agricultural investment, the Ethiopian officials decided to open a Consular Office in Calcutta and, interestingly, appointed Aditya Agarwal as the Honorary Ethiopian Consul in the city (Business Standard 2009). This might be a simple example that shows the urge of the government to expand large-scale agricultural investment without properly undertaking the benefits and liabilities of such decisions. However, the company managers made use of their invitation and relationship with higher officials as leverage not to follow any of the normative land acquisition procedures (discussion with key informants). For instance, the company did not conduct socioeconomic, environmental, and technical assessments before embarking on the operation, although these are the Ethiopian government's preconditions for large-scale agricultural investments. Even the very basic soil and climatic assessments were not undertaken. A document about land identification from Oromia Investment Bureau concerning this specific site shows that groundwater and labor availability were the two major conditions that were taken into consideration to identify and allocate the land for large-scale Jatropha investment, though the former was not available in suitable quantities. However, Emami Biotech is not the first and only company to circumvent these conditions, as they could always be selectively applied based on the interest of the government actors.

The process of land allocation ignored the fact that more than 3000 agropastoral people inhabited the 11,000 ha of land acquired by Emami Biotech (Central Statistical Authority 2007). Miesso District is semi-arid lowland, and the inhabitants engage mainly in livestock herding and rainfed crop cultivation. Maize and sorghum are the dominant cereal crops in the area. With annual rainfall less than $750 \mathrm{~mm}$, access to water is a major limiting factor for agricultural production. Although consultation with the local community is among the government's preconditions for largescale agricultural investment, no consultation of any kind occurred before the land was handed over to the investor.

The participation of the lower level administrations; i.e., the district and the Kebele (the lowest level in the administrative structure, also called Peasant/Pastoralist Associations), was also minimal. Both the land identification and leasing out to the investor were made exclusively by the Oromia Investment Bureau located in Addis Ababa without any consultation with the local community. In fact, the community claims to have heard about the land lease only when the investor arrived accompanied by officials from the Oromia Investment Bureau and from the different levels of the administration structures for official takeover of the land. Similarly, the Kebele administration, which is an institution closest to the community, was contacted and informed only when the officials went down to the field to hand over the land to the investor. Our informant, who was a chairman of one of the affected Kebeles, narrated the situation as follows:

One day, I was summoned from my home. When I went to the roadside I saw many officials with seven vehicles 
(five of them from the Oromia regional government offices in Addis Ababa, and one each from West Hararghe Zone and Miesso District administration offices). The officials greeted me and requested me to call the Kebele security personnel. I called them, and we all went out to the field. Then they informed us that a vast land in the area had been granted to a foreign investor. The officials pointed to a man with an Indian complexion that was granted the land. We were shocked and asked the officials to inform the community about it before they take any further step. They rejected out concerns and demands saying that 'as the land was granted by the Oromia Investment Bureau, it is not subject to any discussion.' They soon started measuring the land... (interview with Kebele Chairman).

This quotation shows how much the land acquisition process was top-down and failed to be inclusive of the local administration and the local community. Similarly, emphasizing such a top-down approach, one of our FGD participants said, "Considering that they (the investors) have completed everything from above (at the regional and federal government offices), they came and landed out of the blue like an airplane." Both quotations indicate that the investors and high-level government bodies did not consult and properly engage the local community who physically reside and whose livelihood depends on the very land given out to the investor.

During our discussion, the investment authorities in Addis Ababa argued citing the Federal Land Law of 2005, which declares that the government can decide to transfer communal land (land communally used by pastoralists) to private holdings if it deems it necessary (Article 5). However, Article 40 of the 1995 constitution declares that Ethiopian pastoralists "have the right to free land for grazing and cultivation as well as the right not to be displaced from their own lands." Despite the constitutional provision that "Land is a common property of the Nations, Nationalities and Peoples of Ethiopia...," the authorities, not the people, decide which legal body to emphasize.

The process marginalized and dispossessed the agropastoralists of their basic means of livelihood. This was partly related to the mis/conception of the pastoral lowlands as "underutilized" land (Borras et al. 2010, Makki 2014), coupled with the government's aggressive involvement in land grabbing to fulfill its national targets, such as the biofuel strategic plan and response to a shortage of foreign currency. These factors, which are part of the general failure in land governance regime in the country, have vitally shaped the future interactions between the local people, the investor, and the government, leading to competition and conflict over land and water.

\section{A promise of a Jatropha-based economic hub}

Emami Biotech encountered local protest when it arrived with bulldozers and numerous heavy agricultural machineries to start land clearing in the spring of 2009. Villagers came out en masse and tried to stop the investor and the machines from entering the site. Administrative officials from zonal and district levels intervened. Public engagement sessions were organized to engage the affected agropastoralists and facilitate future cooperation between the company and the community. However, the company manager negotiated the situation by creating a "Jatropha hype."
He promised "to transform the area from poor food aid recipient to an economic hub that would even support people from beyond the region" (interview with former employee of Emami Biotech). Firstly, he presented the potential of the company as being able to employ many thousands of workers on the farm and in the processing plant. This related the promises of the investment to the life of the local people in a very concrete way. Following this, many of the government employees working in the agriculture offices of the nearby districts applied for job opportunities in this "promising foreign company." Secondly, the company manager pledged a number of highly ambitious infrastructural packages to support the local community. These included building a high school, setting up a clinic, and providing electricity and a potable water supply. The promises to improve the basic services, which are terribly lacking in the area, have apparently been used as a strategy to quell the unexpected and growing resistance by the local community.

Even more important in building the "Jatropha hype" was a presentation of the business plan of the Jatropha investment in a local language during the community engagement session. Key informants had a vivid memory of a very impressive manner in which the presentation was made. Local people have known the wild Jatropha plant for a long time, and the maximum benefit they had managed to make out of it was to use it as live fence. The presenter fascinated the community by presenting Jatropha as a crucial resource that could solve two of the major problems of the country and the locality: fuel and income. He promised to set up an oil processing plant in the nearby small town of Bordede and presented to them an appealing plan that would turn the "worthless Jatropha" into an aviation fuel. He repeatedly mentioned the production of "aviation fuel" from Jatropha, thereby creating an inflated image of Jatropha among the local people. The company officials wanted to justify the land acquisition and its impact on the local community by creating some fascinating way of explaining the valuable role Jatropha could play in national and local development.

The process of community engagement after the investment decision was made helped convince the local community of the value of the investment, as many people developed curiosity to see Jatropha, which was to be harvested from their fields and would become an "aviation fuel." Some individuals even spoke out publicly, admiring the company as something that had come to transform the poverty-stricken area for the better. In 2010, the company managed to clear more than 1100 ha of land and planted Jatropha on 700 ha. At the beginning, the Jatropha plants flourished and were shown to observers and recounted as a success story. Higher officials, including the president, visited the site on a number of occasions.

With the government's special emphasis on biofuel investment, as seen in the very ambitious strategic plan and the Emami Biotech's well-articulated promises of the contributions of Jatropha in national and local development, it seemed that cooperation between different actors over the cultivation of Jatropha would be possible. However, the relationship turned into competition and conflict over resources very soon.

\section{Competition and conflict over resources}

In the second half of 2010 , as the company started operation, it entered into intense competition with the local community over 
scarce water. The only stream that is used by the community for human consumption and their livestock traverses the company's farm site along its eastern border (Fig. 1). The first competition over this stream was signaled as the company started its Jatropha nursery. At this stage, the company asked the local community to allow it to pump water from the stream to water its Jatropha seedlings until its ponds and boreholes would be ready. Then, the community and the Kebele officials deliberated on the matter, accepted the request, and allowed the company to pump water from the stream to its nursery only in the evening since the stream would not be sufficient during the day. In the meantime, the company dug a few boreholes but without success, though the underground water survey report from the district office of Agriculture showed there was water. The company also developed several small ponds but could not collect as much water as it needed (FGD with community members).

After a while, the company went to the community with more severe demands. Toward the end of 2010, the company requested the use of the river to water its Jatropha seedlings and other intercropped plants, such as maize, pepper, and tomatoes. The community and the Kebele officials refused to accept the request because the river is a critical source of water in the area. Higher officials intervened and put pressure on the local officials and the community to accept the company's demand. The community's resistance to the demand even led to a coercive intervention from the federal army based in the nearby military camp. According to participants of the FGDs, several people were beaten up and many were taken to jail in December 2010. This intensified the tense relationship between the company and the local community, and eroded the community's expectations about the success of the large-scale Jatropha investment.

In their attempt to support the company, top regional government officials visited the farm, and spoke to the community representatives on the issue several times. The repeated interventions, intended to solve the tense relationship, failed to bear fruit, due mainly to the approach and nature of the interventions. The lower administration officials complained about the pressure exerted on them by higher officials "to support the investment at all cost" (interview with a district official). In one of the community engagement sessions, a higher official is said to have contrasted the Ethiopian government's claimed pace of development to the local community's livelihood, and tried to justify the priority given to large-scale investment over the smallholders as follows:

Ethiopia is developing as fast as the rabbits run in this bush. Your (agropastoralists') progress is, to the contrary, as sluggish a tortoise walks. That is no more tolerable. By planting Jatropha this investor would produce aviation fuel. Imagine when petroleum from your field helps airplanes fly. This is the kind of investment our government has been looking for. It is the kind of investment that changes our country in general and the district in particular. We care for this person (the investor) as much as we care for our eyes. I know you have never successfully harvested a quintal of maize from this land. You should be ashamed of the negative attitude you have developed towards this investment for a land you have never effectively utilized (interview with Kebele Chairman).
This extract from an official's speech was a manifestation of the common contrasting view between the state actors and the community about "development" in general and the land expropriated for large-scale investment in particular. The rhetoric of "Ethiopia's fast growing economy" as claimed by the government and confirmed by international financial organizations, such as the World Bank (see, for example, Moller 2015), has been used to legitimize the government development agenda such as large-scale agricultural investments and the related dispossessions. Unfortunately, such acclaimed economic growth and changes have not benefited the lowlanders (see Markakis 2011, Gebresenbet 2016). By persistently accusing the agropastoral community of "sluggish change" and resistant to "development," the elite have played the role of facilitating the dispossession of the agropastoralists (Makki 2012).

Regardless of how much the land is "not effectively utilized" in the eyes of the state actors, the research revealed that the local inhabitants are very much emotional about the value of the land. The difference is that agropastoralists do not weigh the value of land only by the amount of crop they harvest from it. Besides cultivation, which depends on the availability of rain, the land is where they herd thousands of livestock. It is where they perform religious rituals. It is from where they collect firewood and herbal medicines, and the stream is the only water that sustains their lives and their livestock. The nutritional values pastoralists gain from wild plants in the form of food and medicine have been studied in southwestern Ethiopia (LaTosky 2013). The efficacy of their livelihood should have been evaluated in this context.

Instead of creating more benefit to the livelihood of the local community, the company entered into competition and conflict with the locals over the existing scarce water resources. The misconception of government actors about the agropastoral society and the ensuing land governance regime in the lowland areas caused direct harm to the livelihood of the agropastoralists, and as a result, large-scale agricultural investments in Ethiopia, including biofuels, are consistently affected by conflicts (see Desalegn 2011, Yonas 2013, Gebresenbet 2016).

\section{Encroachment on the livelihood of the locals}

Besides the competition and conflict over natural resources such as water and land, the company also encroached on the livelihoods of the locals through its engagement in petty businesses, which tarnished its image in the eyes of the locals. Among these were participation in the small-scale production and sale of pepper, tomatoes, and maize from parts of the land the company acquired for Jatropha. The Indian manager of the company and his local administrative team designed this as a side business to cover some of the expenses the company incurred during the long "payback" period that Jatropha takes to bear fruit. While the pepper and tomatoes were taken to local markets, competing with local sellers, the maize farm suffered from the same problem the local communities' farms had been facing; i.e., shortage of rainfall. The water from the stream, which was the source of conflict between the company and the local community, was not sufficient to sustain the maize plants. The company's inability to grow even maize was a shock for the local community. What they observed on the ground was a complete reversal of what they have been told about the investor's technological and innovative capacity. According to an informant who was an employee of the company, some laborers and guards tried to advise the investor on the maize 
variety that suits the area. He planted a variety that takes longer to mature: the variety that suits the highland climate where rainfall is longer and sufficient. This too put pressure on water resources because the production of maize and vegetables required intensive use of water.

In the view of FGD participants, a further disturbing phenomenon was the company's engagement in the production of charcoal from within the investment sites which were inaccessible to the local community. As part of the preparation of the lands for Jatropha farm, the company pulled down many big trees, mostly indigenous, by using heavy machinery. The company hired two individuals exclusively for the purpose of charcoal production and sale (interview with former farm expert of the company). Although it is illegal (FDRE 2011), selling charcoal by cutting and burning trees is common in the area. Many destitute households do this for survival, and thus, the local charcoal sellers complained that their market shares and price dwindled because of the engagement of the company in selling charcoal. Moreover, some of the big indigenous trees that had been used for hanging traditional beehives were pulled down by the company and finally sold in the form of charcoal. The company's intrusion into local livelihood activities and competition with the locals was further exposed by a woman FGD participant when asked how much the company gave affirmative action to women in job creation and technology transfers: "Let alone to give special consideration for the women, the company engaged in mini businesses by replacing us (the women) in the local markets. This does not deserve the name 'investor'." Another agropastoralist who observed these and other acts of the investor commented that "he (the investor) is as poor as ourselves, if not poorer."

The locals' imaginary image of a foreign investor is someone who is rich, well paying, experienced, and knowledgeable. By engaging in a job even the locals consider to be the domain of the poor, company management traded off long-term gains, the company "s reputation, and sustainability of the investment for short-term insignificant income. For the local community, this simply showed how much the investor was voracious in drawing income from the land with little regard for the interests of the local community who rely on the very land for their livelihood.

\section{Culmination of resistance and abandonment}

In 2011, after about two years of the presence of the company in the area, none of the promises to improve infrastructure in the area was fulfilled: no water, no high school, no electricity, and no clinic. There were far fewer jobs and lower pay than promised. Because the company did not cultivate as much as expected, the number of jobs created were few. According to Mengistu (2013), the company employed up to 160 laborers mainly for land clearing and for planting of Jatropha seedlings at the initial stage, and that number dramatically declined once the first phase of land clearing and planting was completed. As more skilled workers, such as machine operators, were brought from somewhere else, the locals were employed mainly as laborers and guards. This was contrary to the initial promises. These overpromises and under delivery generated mistrust between the company and the local community instead of building mutual interest and interdependence. The people felt that the company abused them, exploiting their destitute economic situation. The company's failure to deliver any of the promises it had made, coupled with competitions over water and other aspects of the local livelihood, intensified the local people's and officials frustration about the company's impact on the area. Especially after the company failed to develop its own sources of water, and rather engaged in a dispute over existing water with the locals, the local community "realized that the company did not only fail to fulfill any of its promises, but also would seriously damage their livelihood in the future" (interview with Kebele Chairman). Then, the community decided, as one of our discussants stressed, "to get rid of the company from the area with the support of the almighty" (interview with a local elder).

The first open confrontation between the local community and the company over water use took place in December 2010. The confrontation met with coercive response from the government actors, including the army, which ended up in several people being physically harmed. The local community continued staging resistance but in different forms. Now they resorted to hidden activities to expel the investor without attracting much attention from the government authorities. Bearing in mind the authoritarian and repressive nature of the Ethiopian political regime, the resistance was not well coordinated or based on systematically organized action. Rather, it was measures taken by individuals and microgroups such as the company's employees, herders, the company's guards, and other members of the community who were disappointed by the company's actions or inactions. Damaging the company's crop, mainly Jatropha, was the main strategy. As one former guard told us, "the laborers themselves were planting Jatropha during the day time only to uproot it in the evening." The community also deliberately drove their cattle into the plantation, causing the company to write to the Oromia Investment Bureau, complaining about crop damage by the local community and their cattle. The action prompted the district administration to devise a new regulation concerning damages caused by the livestock to the investment. According to this regulation, "if a livestock is apprehended in the Jatropha farm, the owner would pay twenty birr per head." The implementation of such a measure was, however, difficult because the guards (disappointed because of the low payment rate) were of no help. According to key informants, they in fact collaborated with the people against the company. When criticized for this by the company, regardless of the difficult livelihood situation, several of the guards resigned from their positions.

Administrative officials also mentioned that staff turnover, especially in the case of guards, was very high during the brief existence of the company. At a certain point, the company started to turn down local applicants in favor of employing guards only from far away areas as a strategy of doing away with the guards' collaboration with the local people. This strategy was, however, counterproductive because it further alienated the company from the local community. It also created a local argument that the company needs only their land not the people (labor), dwarfing the official rhetoric of the government and the company's promises of the investment's trickle-down effect for the local community through job creation. This prompted more people to oppose the company.

The resistance was also supported by a ritual of curse. The Oromo population residing in Bordede practices the Sunni Islamic 
religion. Yet, they usually mix indigenous Oromo religious practices with Islam. Falling out with the investor and unable to obtain the support of the government, the Bordede community turned to traditional prayers. In May 2011, the community gathered under an acacia tree, slaughtered two goats, and conducted a ritual of curse to "uproot" the investment from their locality in a very customary way. According to an elderly informant, they prayed to the Almighty saying:

Oh God! You created us on this land. We know nothing other than this land. An alien guest whom we have never invited has taken our land. May you uproot him! He has nothing but evil intention. He is harming our livelihood. May you uproot him! Oh God, if it is not your intention to bring him, may you uproot him!

This call for divine intervention reveals how desperate the community members were regarding the investment, as other actions were not delivering as quickly as the community needed them to. During our fieldwork, informants mentioned their upset over the whole processes they had passed through in their relationship with the government and the company, but they were also proud of managing to "uproot" the company by using several resistance mechanisms, the prayers considered the most vital from the elders' perspective. Alongside this resistance was, of course, the fact that Jatropha production failed on this site.

In January 2012, Emami Biotech informed the Oromia Investment Bureau that it had abandoned its Jatropha farm and left for good. Its withdrawal was unceremonious. Most community members, including the workers and guards, were informed two months after the company had left. Many guards and laborers were shocked because they were not paid their wages for several months. In terms of the reasons for withdrawal, in addition to the oppositions and resistances from the local community that we have discussed, the company's letter to Oromia Investment Bureau also mentioned technical problems such as shortage of water and unsuitability of the land for Jatropha cultivation. In other words, the company complained about the poor performance of Jatropha in this moisture-stressed semi-arid lowland (see also Mengistu 2013). Of course, shortage of both underground and surface water was so visible that it was one of the main reasons for the conflicts between the company and the local community. Our argument is that the problem related to shortage of water and un/suitability of the soil should have been studied before the land had been allocated for the investment. The company should also have made it certain that these basic conditions had been fulfilled before investing in the land. This has negatively affected the local communities' livelihoods and ambitions for local development.

\section{CONCLUSION}

We have used the historical trajectory of a large-scale biofuel investment in Ethiopia to examine land governance regimes and local conflicts and cooperation over natural resources. The overambitious biofuel development strategy in Ethiopia that coincided, but not by chance, with the global financial, food, and fuel crises of 2007/08 was part of the short-lived global biofuel hype that failed in its local practices. We have contextualized the failure of the national and local promises of biofuel in the broader problem of land governance. Thus, without falling into a "trap of blaming a crop"(White and Dasgupta 2010:13), we have argued that the disappointing outcome of the Jatropha investments in Ethiopia was due to the way the investment processes were conceived and implemented. In other words, a narrowly conceived economic urge has guided the Ethiopian government's biofuel strategy at the expense of considerations of the livelihood needs of the local people. This has caused a short-lived rush for biofuel investment generation that has resulted not only failure in the investments but also in giving rise to resource-based conflicts. This case study showed that the failure of government policy was worsened by the way the Indian company took up the challenges.

This Ethiopian case does not stand alone; it is part of a trend. The final decade has seen huge hype over Jatropha, which was pushed globally as a "wonder crop" offering huge benefits and creating win-win situations to mitigate climate change, secure energy, offer smallholders new sources of income, etc. (FAO 2008, Mengistu 2013). Investment in Jatropha spread around the world from Ghana to Ethiopia, from Vietnam to Indonesia and India, and from Mexico to Guatemala. Land has been reallocated in favor of Jatropha producers, often at the cost of the local people living on marginal lands. However, within a short period, it generated competition and conflict over resources, mainly land but also water and other resources on which impoverished people may depend (such as fuel wood for charcoal production), and failed to result in the expected benefits (Janssen 2009, Kumar et al. 2012, Timko et al. 2014).

We have conceptualized competition and conflict over natural resources not as natural or caused by resource scarcity, per se, but as phenomena caused by the failure in the governance regime (see Frerks et al. 2014). In the case of Ethiopia, the strategies of largescale agricultural investment, including biofuel, have been very ambitious and were meant to address national problems such as fuel crises and foreign currency shortage. However, using local natural resources such as land and water without consultation with affected local people stimulates conflict. To justify investment, the government represented the pastoralist and agropastoralist frontiers as empty, and idle land that is not legitimately owned and utilized but full of resources that can be appropriated as a national good. Such government bias toward large-scale agricultural investment at the expense of the smallholders in the lowland agropastoral areas has resulted in conflicts, leaving the whole development endeavors "neither profitable nor pro-poor." The major victims in this game are the local communities whose losses are multiple: land, water, and local stability. This competition and conflict over the natural resources has caused failure in the sustainable use of the locally available resources for both local and national development.

Responses to this article can be read online at: http://www.ecologyandsociety.org/issues/responses. php/10486

\section{Acknowledgments:}

This article is a result of research conducted in Ethiopia as part of the Conflict and Cooperation over Natural resources (CoCooN) programme funded by the Netherlands Ministry of Foreign Affairs. We thank the Ministry for generously funding the project. We would 
also like to thank the two anonymous reviewers, and Mamo Hebo, a colleague in the Department of Social Anthropology at Addis Ababa University, for his constructive comments on the draft of the paper.

\section{LITERATURE CITED}

Abbink, G. J., K. Askew, D. F. Dori, E. Fratkin, E. C. Gabbert, J. Galaty, S. LaTosky, J. Lydall, H. A. Mahmoud, J. Markakis, G. Schlee, I. Strecker, and D. Turton. 2014. Lands of the future: transforming pastoral lands and livelihoods in Eastern Africa. Working paper No. 154. Max Planck Institute for Social Anthropology, Halle, Germany.

Abreham, B., and B. Zerga.2015. Biofuel energy for mitigation of climate change in Ethiopia. Journal of Energy and Natural Resources 4(6): 62-72. [online] URL: http://dx.doi.org/10.11648/ j.jenr.20150406.11

Ayalew, G. 2012. The dynamics of land transaction practices among the Karrayu pastoralists in the Upper Awash Valley of Ethiopia: the cases of Abadir and Merti communities. Eastern Africa Social Science Research Review 28(1).

Borras, S. M., Jr., P. D. McMichael, and I. Scoones. 2010. The politics of biofuels, land and agrarian change: editors' introduction. Journal of Peasant Studies 37(4):575-592. http://dx. doi.org/10.1080/03066150.2010.512448

Bridge, G. 2001. Resource triumphalism: postindustrial narratives of primary commodity production. Environment and Planning A33:2149-2173. http://dx.doi.org/10.1068/a33190

Business Standard. 2009. Emami Biotech to set up biofuel project in Ethiopia. [online] URL: https://www.business-standard.com/ article/companies/emami-biotech-to-set-up-biofuel-project-inethiopia-109080400082 1.html

Central Statistical Authority. 2007. 2007 population and housing census of Ethiopia. Addis Ababa, Ethiopia.

Cotula, L., S. Vermeulen, R. Leonard, and J. Keeley. 2009. Land grab or development opportunity? Agricultural investment and international land deals in Africa. IIED/FAO/IFAD, London/ Rome.

Deininger, K., D. Byerlee, J. Lindsay, A. Norton, H. Selod, and M. Stckler. 2011. Rising global interest in farmland: Can it yield sustainable and equitable benefits? International Bank for Reconstruction and Development/World Bank. Washington, D. C., USA.

Dessalegn, R. 2011. Land to investors: large-scale land transfers in Ethiopia. Forum for Social Studies, Addis Ababa, Ethiopia. [online] URL: http://www.landgovernance.org/system/files/ Ethiopia Rahmato FSS 0.pdf

Federal Democratic Republic of Ethiopia (FDRE). 1995. Constitution of the Federal Democratic Republic of Ethiopia. Addis Ababa, Ethiopia.

Federal Democratic Republic of Ethiopia (FDRE). 2011. The Federal Democratic Republic of Ethiopia Environmental Protection Authority. GEF Portfolio Identification Document. December 2011. Addis Ababa, Ethiopia.
Food and Agricultural Organization of the United Nations (FAO). 2008. The state of food and agriculture. Biofuels: prospects, risks, and opportunities. Rome, Italy.

Frerks, G., A. J. Diez, and P. Van Der Zaag. 2014. Conflict and cooperation on natural resources: justifying the $\mathrm{CoCooN}$ program. Pages 13-34 in M. Bavinck, L. Pellegrini, and E. Mostert, editors. Conflict over natural resources in global south conceptual approaches. CRS Press, London, UK.

Gebresenbet, F. 2016. Land acquisition, the politics of dispossession, and state-remaking in Gambella, Western Ethiopia. Africa Spectrum 51(1):5-28.

Gill, B. 2015. Can the river speak? Epistemological confrontation in the rise and fall of the land grab in Gambella, Ethiopia. Environment and Planning A: Economy and Space 48(4):699-717. http://dx.doi.org/10.1177/0308518X15610243

Hall, D. 2013. Primitive accumulation by dispossession and the global land grab. Third World Quarterly 34(9):1582-1604.

Hussein, J. 2001. The debate over land tenure policy options in Ethiopia: review of the post 1991 contending views. Ethiopian Journal of Development Research 23(2):35-84.

Janssen, N. 2009. Jatropha development in Vietnam: growing alternative energy on waste lands: a case of win-win for a biofuel company and smallholder farmers. SNV, The Hague, Netherlands.

Keeley, J., W. Michago, A. Eid, and A. Lokaley. 2014. Large-scale land deals in Ethiopia: scale, trends, features and outcomes to date. IDRC and IIED, London, UK.

Korf, B., T. Hagmann, and R. Emmenegger. 2015. Re-spacing African drylands: territorialization, sedentarization and indigenous commodification in the Ethiopian pastoral frontiers. Journal of Peasant Studies 42(5):881-901. http://dx.doi. org/10.1080/03066150.2015.1006628

Kumar, S., A. Chaube, and S. K. Jain. 2012. Importance of Jatropha curcas in Indian economy. Pages 13-30 in N. Carels, M. Sujatha, and B. Bahadur, editors. Jatropha, challenges for a new energy crop. Vol. 1: farming, economics and biofuel. Springer, New York, USA. http://dx.doi.org/10.1007/978-1-4614-4806-8 2

LaTosky, S. 2013. Predicaments of Mursi (Mun) women in Ethiopia's changing world. Koeppe, Cologne, Germany.

Lavers, T. 2012. Patterns of agrarian transformation in Ethiopia: state-mediated commercialisation and the ' land grab'. Journal of Peasant Studies 39(3-4):795-822. http://dx.doi.org/10.1080/0306$\underline{6150.2012 .660147}$

Lorenzo, C., S. Vermulen, R. Leonardo, and J. Keeley. 2009. Land grab or development opportunity? Agricultural investment and international land deals in Africa. FAO, IIED, and IFAD.

Makki, F. 2012. Power and property: commercialization, enclosure, and the transformation of agrarian relations in Ethiopia. Journal of Peasant Studies 39(1):81-104.

Makki, F. 2014. Development by dispossession: Terra Nullius and the social-ecology of new enclosures in Ethiopia. Rural Sociology 79(1):79-103. http://dx.doi.org/10.1111/ruso.12033 
Markakis, J. 2011. Ethiopia the last two frontiers. James Currey Press, UK and USA.

MELCA Mahiber. 2005. Rapid assessment of biofuels development status in Ethiopia. Addis Ababa, Ethiopia.

MELCA Mahiber. 2008. Rapid assessment of biofuels development status in Ethiopia and proceedings of the national workshop on environmental impact assessment and biofuels. [online] URL: http://melcaethiopia.org/wp-content/uploads/2011/05/ Eth_Biofuel_Assessment-Final.pdf

Mengistu, A. W. 2013. Jatropha potential on marginal lands in Ethiopia: reality or myth? IFRO Working Papers 2013/17. [online] URL: http://okonomi.foi.dk/workingpapers/WPpdf/WP2013/ IFRO WP 2013 17.pdf

Ministry of Agriculture and Rural Development (MoARD). 2006. Agricultural policies, programs and targets for a plan for accelerated and sustainable development to end poverty (PASDEP) 2005/2006-2009/2010. Addis Ababa, Federal Democratic Republic of Ethiopia.

Ministry of Agriculture and Rural Development (MoARD). 2010. Ethiopia's agricultural sector policy and investment framework 2010-2010. Addis Ababa, Federal Democratic Republic of Ethiopia.

Ministry of Finance and Economic Development (MoFED). 2010. Growth and Transformation Plan (GTP). Addis Ababa, Federal Democratic Republic of Ethiopia.

Ministry of Mine and Energy (MME). 2007. Ethiopian biofuels development and utilization strategy. Addis Ababa, Federal Democratic Republic of Ethiopia.

Moller, L. C. 2015. Ethiopia's great run: the growth acceleration and how to pace it. World Bank Group, Washington, D.C., USA. [online] URL: http://documents.worldbank.org/curated/ en/693561467988949839/Ethiopia-s-great-run-the-growth-accelerationand-how-to-pace-it

Oakland Institute. 2010. (Mis) investment in agriculture: the role of the international finance corporation in global land grabs. Oakland, California, USA.

Oakland Institute. 2011. Understanding land investment deals in Africa, country report: Ethiopia. Oakland, California, USA.

Schoneveld, G. C. 2014. Governing large-scale farmland investments in sub-Saharan Africa: challenges and ways forward. CIFOR Infobrief No. 72.

Tewolde, W., and F. Gebresenbet. 2014. Socio-political and conflict implications of sugar development in Salamago Wereda, Ethiopia. Pages 117-143 in M. Gebrehiwote, editor. A delicate balance: land use minority rights and social stability in the Horn of Africa. Institute of Peace and Security Studies, Addis Ababa, Ethiopia.

Timko, J. A., A. Amsalu, E. Acheampong, and M. K. Kinfu. 2014. Local perceptions about the effects of Jatropha (Jatropha curcas) and Castor (Ricinus communis) plantations on households in Ghana and Ethiopia. Sustainability 6(10):7224-7241. http://dx. doi.org/10.3390/su6107224
White, B., and A. Dasgupta. 2010. Agrofuels capitalism: a view from political economy. Journal of Peasant Studies 37(4):593-607. http://dx.doi.org/10.1080/03066150.2010.512449

Yonas, T. 2013. The impact of large-scale agricultural land acquisition on local communities: the case of Bako Tibe District, West Oromia. Thesis. Addis Ababa University, Addis Ababa, Ethiopia. 